\title{
Rhodobium gokarnense sp. nov., a novel phototrophic alphaproteobacterium from a saltern
}

Correspondence

Ch. V. Ramana

r449@sify.com or

sasi449@yahoo.ie
The genus Rhodobium is composed of marine species that are capable of photosynthesis, multiply by budding and possess lamellar internal membrane structures (Hiraishi et al., 1995). At present, the genus Rhodobium comprises two species, both of which were isolated from marine sediments: Rhodobium marinum (originally described as Rhodopseudomonas marina, Imhoff, 1983); and Rhodobium orientis (Hiraishi et al., 1995). Strain JA173 ${ }^{\mathrm{T}}$, which was isolated from a saltern, is described in this report and, based on its phylogenetic and phenotypic properties, which are distinct from those of the other Rhodobium species, it is proposed that this strain represents a novel species in this genus.

Abbreviation: FTIR, Fourier-transform infrared.

The GenBank/EMBL/DDBJ accession number for the 16S rRNA gene sequence of strain $\mathrm{JA} 173^{\top}$ is $\mathrm{AM} 180706$.

A phase contrast micrograph, an electron micrograph, absorption spectra and FTIR spectra of strain $\mathrm{JA}_{173^{\top}}$ are available as supplementary material in IJSEM Online.
Soil and water, including salt crystals, were collected on 27 December 2003 at around midday from a saltern located in Gokarna, India. GPS positioning of the sample collection site was $14^{\circ} 32^{\prime} \mathrm{N} 74^{\circ} 19^{\prime} \mathrm{E}$. The sample yielding strain $\mathrm{JA} 173^{\mathrm{T}}$ had a $\mathrm{pH}$ of 6.8 and a temperature of $30^{\circ} \mathrm{C}$. Strain JA173 ${ }^{\mathrm{T}}$ was isolated from photoheterotrophic enrichments of this soil sample. Purification and polyphasic taxonomic studies were carried out as described previously (Srinivas et al., 2006). Fourier-transform infrared (FTIR) spectroscopic analysis data (Ramana et al., 2006) of strain JA173 were compared with those of cells of Rhodobium orientis DSM $11290^{\mathrm{T}}$. DNA-DNA hybridization was carried out at the DSMZ (Braunschweig, Germany) using a spectrophotometric method (De Ley et al., 1970; Huß et al., 1983) after chromatographic (hydroxyapatite) purification of DNA (Cashion et al., 1977).

Individual cells of strain $\mathrm{JA}_{173^{\mathrm{T}}}$ were rod-shaped, 0.5$0.6 \mu \mathrm{m}$ wide and $1.0-2.0 \mu \mathrm{m}$ long, non-motile and multiplied by budding (see Supplementary Fig. S1 in IJSEM Online). An electron micrograph of ultrathin sections of the 
cells revealed lamellar internal membrane structures (see Supplementary Fig. S2 in IJSEM Online). Strain JA173 ${ }^{\mathrm{T}}$ was able to grow photoorganoheterotrophically in the presence of incandescent light (optimum light intensity, 10004000 lux) (anaerobic; light, 2400 lux) and chemoorganoheterotrophically and aerobically in the dark with pyruvate $(0.3 \%, w / v)$. Photolithoautotrophic growth (anaerobic; light, 2400 lux; $20 \% \mathrm{H}_{2}$, v/v; $0.5 \mathrm{mM} \mathrm{Na}_{2} \mathrm{~S} ; 0.5 \mathrm{mM}$ $\mathrm{Na}_{2} \mathrm{~S}_{2} \mathrm{O}_{3}$; and $\left.0.1 \% \mathrm{NaHCO}_{3}, \mathrm{w} / \mathrm{v}\right)$, chemolithoautotrophy (aerobic; dark; $0.5 \mathrm{mM}$ thiosulfate; and $0.1 \% \mathrm{NaHCO}_{3}$, $\mathrm{w} / \mathrm{v}$ ) and fermentative growth (anaerobic; dark; $0.3 \%$ glucose, w/v; $0.3 \%$ fructose, w/v) could not be demonstrated.
Substrates that were utilized as carbon sources/electron donors under photoorganoheterotrophic conditions included acetate, butyrate, pyruvate, citrate, succinate, fumarate, malate, glucose, mannitol, sorbitol and Casamino acids (Table 1). Formate, propionate, valerate, caproate, caprylate, lactate, tartrate, benzoate, fructose, glycerol, methanol, ethanol, glutamate, peptone and yeast extract could not be utilized. Thiosulfate, sodium sulfide and $\mathrm{H}_{2}$ (with $0.1 \%$ $\mathrm{NaHCO}_{3}$ ) were not utilized as electron donors under photolithoautotrophic conditions. Ammonium chloride, molecular nitrogen and glutamine were utilized as nitrogen sources, whereas urea, glutamate, nitrate and nitrite did not

\section{Table 1. Characteristics that differentiate species of the genus Rhodobium}

Data for Rhodobium orientis are from Hiraishi et al. (1995). Data for Rhodobium marinum are from Imhoff (1983) and Imhoff \& Hiraishi (2005); organic substrate utilization for this species was tested during photoheterotrophic growth. Acetate, butyrate, fumarate, D-glucose, malate, pyruvate, sorbitol and succinate are utilized by all taxa, whereas benzoate, methanol and tartrate are not utilized. All taxa exhibited sessile budding and are pink-red in culture. + , Substrate utilized or present; - , substrate not utilized or absent; $+/-$, variable reaction in different strains; $(+)$, weak growth or microaerobic growth only; $[+]$, weak growth; ND, not determined; NI, no information.

\begin{tabular}{|c|c|c|c|}
\hline Characteristic & Rhodobium orientis & Rhodobium marinum & Strain JA173 ${ }^{\mathrm{T}}$ \\
\hline Cell size $(\mu \mathrm{m})$ & $1.5-3.2 \times 0.7-0.9$ & $1.0-2.5 \times 0.7-0.9$ & $1.0-2.0 \times 0.5-0.6$ \\
\hline Rosette formation & $+1-$ & - & + \\
\hline Low absorption maximum at ca. $800 \mathrm{~nm}$ & - & + & - \\
\hline Whole cell absorption maxima (nm) & $\begin{array}{c}377,468,500,530 \\
591,802,870\end{array}$ & $\begin{array}{c}375,483,516,533 \\
590,803,883\end{array}$ & $\begin{array}{c}370,402,488,530 \\
590,803,872\end{array}$ \\
\hline $\mathrm{NaCl}$ range (optimum) (\% w/v) & $2-8(4-5)$ & $1-5(1-3)$ & $0.5-10.0(2.0-6.0)$ \\
\hline pH range (optimum) & $6.0-8.5(7.0-7.5)$ & NI $(6.9-7.1)$ & $5.0-9.0(6.5-8.0)$ \\
\hline Vitamin(s) required & $\begin{array}{c}\text { Biotin, } p \text { - } \\
\text { aminobenzoic acid }\end{array}$ & ND & Yeast extract \\
\hline \multicolumn{4}{|l|}{ Utilization of carbon source/electron donor: } \\
\hline Caproate, D-fructose, valerate & + & + & - \\
\hline Caprylate, ethanol, glycerol, propanol, propionate & - & $+1-$ & - \\
\hline Citrate & - & - & {$[+]$} \\
\hline Formate & - & + & - \\
\hline Glutamate & $+1-$ & $\mathrm{NI}$ & - \\
\hline Lactate & + & $+1-$ & - \\
\hline Mannitol & $+1-$ & + & + \\
\hline
\end{tabular}

${ }^{\star} \mathrm{Q}-10$, Ubiquinone $10 ; \mathrm{MK}-10$, menaquinone 10. 
support growth. Strain $\mathrm{JA} 173^{\mathrm{T}}$ required yeast extract as a growth factor. Salt $(\mathrm{NaCl})$ was obligatory for the growth of strain $\mathrm{JA}_{173}{ }^{\mathrm{T}}$; this strain grew in $0.5-10.0 \%(\mathrm{w} / \mathrm{v}) \mathrm{NaCl}$, with optimum growth at $2.0-6.0 \%(\mathrm{w} / \mathrm{v}) \mathrm{NaCl}$. Strain $\mathrm{JA}_{173}{ }^{\mathrm{T}}$ grew at $\mathrm{pH}$ 5.0-9.0, with optimum growth at $\mathrm{pH}$ 6.5-8.0. The temperature optimum for growth was $30 \pm 2{ }^{\circ} \mathrm{C}$.

The colour of the phototrophically grown cell suspension was pink to pink-red. The whole cell absorption spectrum of strain $\mathrm{JA} 173^{\mathrm{T}}$ showed absorption maxima at $370,402,488$, 530, 590, 803 and $872 \mathrm{~nm}$, thus confirming the presence of bacteriochlorophyll $a$ and most probably carotenoids of the spirilloxanthin series (see Supplementary Fig. S3a, b in IJSEM Online). The cellular components (metabolomes) of strain $\mathrm{JA} 173^{\mathrm{T}}$ were compared with those of Rhodobium orientis DSM $11290^{\mathrm{T}}$ under identical growth conditions using whole cell FTIR spectra (see Supplementary Fig. S4 in IJSEM Online), which clearly indicated differences between the two strains. Variations were recorded in the proteins (1650-1580 $\left.\mathrm{cm}^{-1}\right)$, carbohydrates $\left(1200-900 \mathrm{~cm}^{-1}\right)$ and aromatic compounds $\left(870-675 \mathrm{~cm}^{-1}\right)$. No major differences were observed in lipids and fatty acids (3100$\left.2800 \mathrm{~cm}^{-1}\right)$. An ester peak $\left(1728 \mathrm{~cm}^{-1}\right)$ was observed in strain $\mathrm{JA} 173^{\mathrm{T}}$ alone, which is similar to that observed in Rubrivivax gelatinosus DSM $17011^{\mathrm{T}}$ (Ramana et al., 2006). The DNA G $+\mathrm{C}$ content of strain JA173 ${ }^{\mathrm{T}}$ was $72.4 \mathrm{~mol} \%$ (determined by HPLC). The phylogenetic relationship of strain $\mathrm{JA}_{173^{\mathrm{T}}}$ to other purple nonsulfur bacteria was examined by $16 \mathrm{~S}$ rRNA gene sequencing (Fig. 1). The data obtained revealed that the novel isolate branched separately, but was affiliated with the type strains of Rhodobium species. The highest sequence similarities to strain $\mathrm{JA} 173^{\mathrm{T}}$ were found with the type strains of Rhodobium orientis (98\%) and Rhodobium marinum (94\%). However, DNA-DNA hybridization with Rhodobium orientis DSM $11290^{\mathrm{T}}$ revealed a relatedness value of only $35.1 \%$ with strain JA173 ${ }^{\mathrm{T}}$. Apart from 16S rRNA gene sequence dissimilarity and DNA-DNA hybridization studies, strain $\mathrm{JA}_{173^{\mathrm{T}}}$ clearly differed from other Rhodobium species in its phenotypic properties (Table 1); these results justify the description of this strain as a representative of a novel species, Rhodobium gokarnense sp. nov.

\section{Description of Rhodobium gokarnense sp. nov.}

Rhodobium gokarnense (go'kar.nense. L. neut. adj. gokarnense pertaining to Gokarna, the place from which the type strain was isolated).

Cells are rod-shaped, $0.5-0.6 \times 1.0-2.0 \mu \mathrm{m}$, non-motile and divide by budding. Growth occurs under anaerobic conditions in the light (photoorganoheterotrophy) or under aerobic conditions in the dark (chemoorganoheterotrophy). Internal photosynthetic membranes have a lamellar structure. Phototrophic cultures are pink to pinkish-red. The in vivo absorption spectrum of intact cells in sucrose exhibits maxima at 370, 402, 488, 530, 590, 803 and $872 \mathrm{~nm}$,

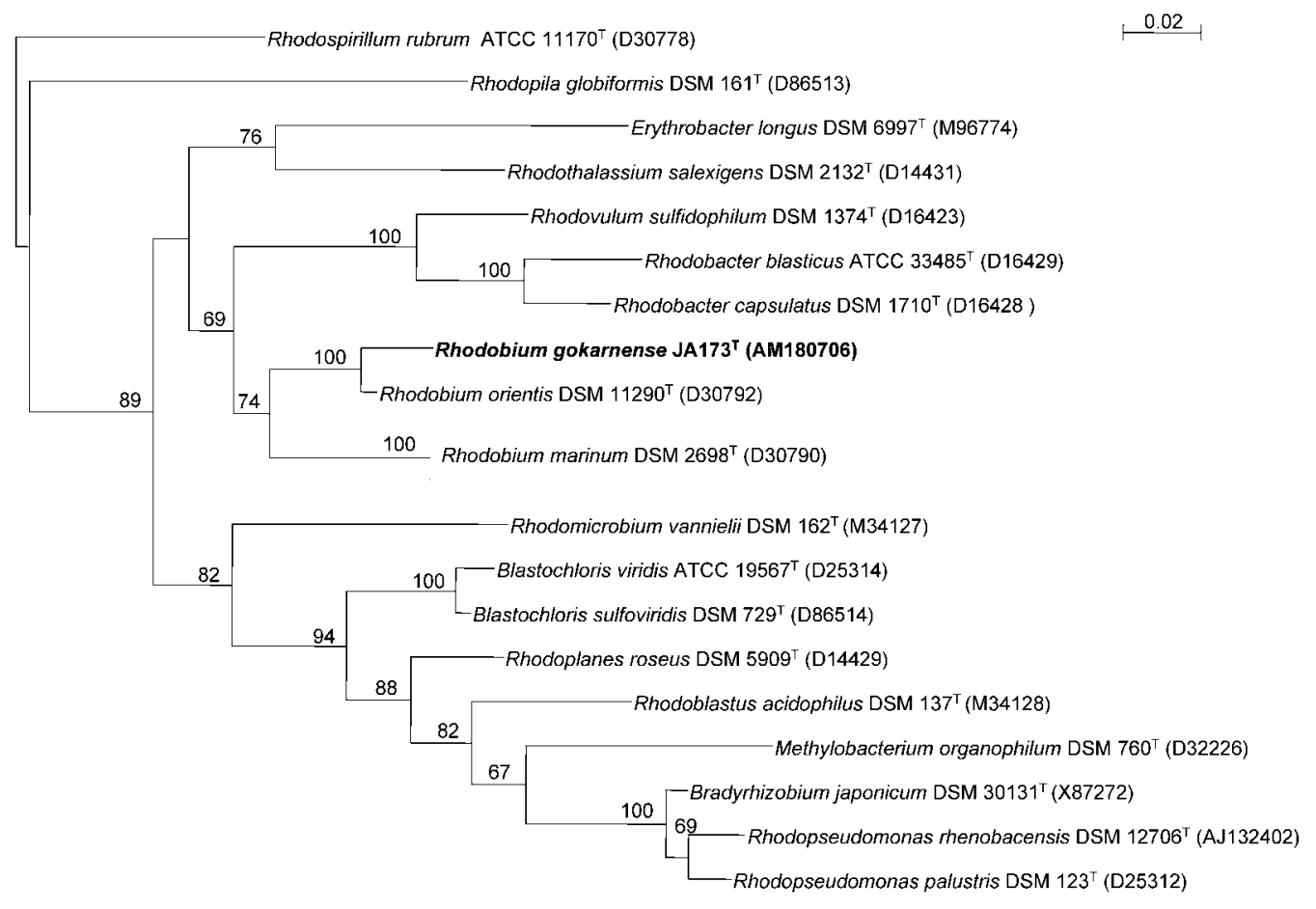

Fig. 1. Dendrogram depicting the phylogenetic relationships of strain $\mathrm{JA} 173^{\top}$ within the family Rhodobiaceae determined using 16S rRNA gene sequence analysis. Bar, 2 substitutions per 100 nucleotides. 
confirming the presence of bacteriochlorophyll $a$ and probably the spirilloxanthin series. Mesophilic $\left(30^{\circ} \mathrm{C}\right)$, with optimum growth at $\mathrm{pH}$ 6.5-8.0. Requires 2.0-6.0\% $(\mathrm{w} / \mathrm{v}) \mathrm{NaCl}$ for optimal growth. Photoorganoheterotrophy with various organic compounds is the preferred mode of growth. Good carbon sources are pyruvate and fumarate. Growth also occurs on acetate, butyrate, citrate, succinate, malate, glucose, mannitol, sorbitol and Casamino acids. Photoautotrophic and chemoautotrophic growth is not possible in the presence of sulfide/thiosulfate/hydrogen as electron donor and $\mathrm{NaHCO}_{3}$ as carbon source. Yeast extract is required as a growth factor. The DNA G $+\mathrm{C}$ content of the type strain is $72.4 \mathrm{~mol} \%$ (by HPLC).

The type strain, JA173 ${ }^{\mathrm{T}}$ (=ATCC BAA- $1215^{\mathrm{T}}=\mathrm{DSM}$ $17935^{\mathrm{T}}=\mathrm{JCM} 13532^{\mathrm{T}}$ ), was isolated from a saltern in Gokarna, India.

\section{Acknowledgements}

Financial assistance received from Department of Biotechnology and Department of Ocean Development, Government of India is acknowledged. P. A. K. and T.N.R.S. acknowledge the CSIR, Government of India, for the award of JR \& SR fellowships. The skilful assistance of F. Lappe (IFM-GEOMAR, Kiel) in molecular analysis is kindly acknowledged. Financial assistance received under DST-DAAD exchange program (grant 422-PPP-34105) is acknowledged.

\section{References}

Cashion, P., Holder-Franklin, M. A., McCully, J. \& Franklin, M. (1977). A rapid method for the base ratio determination of bacterial DNA. Anal Biochem 81, 461-466.

De Ley, J., Cattoir, H. \& Reynaerts, A. (1970). The quantitative measurement of DNA hybridization from renaturation rates. Eur $J$ Biochem 12, 133-142.

Hiraishi, A., Urata, K. \& Satoh, T. (1995). A new genus of marine budding phototrophic bacteria, Rhodobium gen. nov., which includes Rhodobium orientis sp. nov. and Rhodobium marinum comb. nov. Int J Syst Bacteriol 45, 226-234.

Huß, V. A. R., Festl, H. \& Schleifer, K. H. (1983). Studies on the spectrophotometric determination of DNA hybridization from renaturation rates. Syst Appl Microbiol 4, 184-192.

Imhoff, J. F. (1983). Rhodopseudomonas marina sp. nov., a new marine phototrophic purple bacterium. Syst Appl Microbiol 4, 512-521.

Imhoff, J. F. \& Hiraishi, A. (2005). The phototrophic bacteria. In Bergey's Manual of Systematic Bacteriology, 2nd edn, vol. 2, part C, pp. 571-574. Edited by D. J. Brenner, N. R. Krieg \& J. T. Staley. New York: Springer.

Ramana, Ch. V., Sasikala, Ch., Arunasri, K., Anil Kumar, P., Srinivas, T. N. R., Shivaji, S., Gupta, P., Süling, J. \& Imhoff, J. F. (2006). Rubrivivax benzoatilyticus sp. nov., an aromatic hydrocarbon-degrading purple betaproteobacterium. Int J Syst Evol Microbiol 56, 2157-2164.

Srinivas, T. N. R., Anil Kumar, P., Sasikala, Ch., Ramana, Ch., V., Süling, J. \& Imhoff, J. F. (2006). Rhodovulum marinum sp. nov., a novel phototrophic purple non-sulfur alphaproteobacterium from marine tides of Visakhapatnam, India. Int J Syst Evol Microbiol 56, 1651-1656. 